\title{
Felhasználóközpontú szempontok különböző módú megjelenése a szoftverfejlesztésben - Kvalitatív kutatás a hazai cégek gyakorlatáról
}

\author{
Szabó Bálint \\ Budapesti Műszaki és Gazdaságtudományi Egyetem
}

\begin{abstract}
A TANULMÁNY CÉLJA
A kutatás célja a különböző típusú szoftvertermékek elő́llítási folyamatának megismerése abból a szempontból, hogy abban a gyakorlatban a felhasználóközpontú szempontok hogyan jelennek meg. A kutatás tehát a szoftverfejlesztés modelljeinek gyakorlati megvalósításaiban kívánja megtalálni a használhatóság és a felhasználói élmény (User eXperience) szempontjainak és módszereinek szerves helyét.
\end{abstract}

\begin{abstract}
ALKALMAZOTT MÓDSZERTAN
A szoftvercégek jelenlegi gyakorlata interjúsorozat segítségével tárható fel alaposan. Egy megfelelően változatos 15-20 fős, szakmai vezetőkből álló mintán elvégzett kutatás segítségével a cégek gyakorlata és a válaszadók témával kapcsolatos gondolkodásmódja megismerhető. Jelen cikk ennek a nagyobb kutatásnak a kutatási kérdéseit és előzetes eredményeit mutatja be öt igen különböző interjú kvalitatív összegzésének a segítségével.
\end{abstract}

\section{LEGFONTOSABB EREDMÉNYEK}

Az elözetes eredmények jól szemléltetik, hogy a szoftverfejlesztési folyamatokban eltérések vannak. Azok eltérö lépések mentén, különböző eszközök alkalmazásával valósulnak meg, így a felhasználók bevonása is eltérő pontokon, más-más módszerek alkalmazásával történik. A fejlesztések a legtöbb esetben agilis módon történnek, de ennek ellenére azokban a vártnál kevesebb a visszacsatolás. Ugyan a vállalatok jelentős részénél már agilis fejlesztés zajlik, de úgy tűnik, hogy nem ez a tényező határozza meg a szervezetek UX-es érettségét. A UX érettség magasabb azoknál a vállalatoknál, ahol a felhasználóközpontú megközelítéssel foglalkozó csapatok tevékenységeke a szervezet egészére kiterjed. A kapott eredmények alapján továbbá elmondható az is, hogy az empirikus módszereket alkalmazó közép- és nagyvállalatok a méretüktöl függetlenül tudatosabban és sikeresebben implementálták a UX-es folyamatokat. Az eredmények alapján elmondható az is, hogy a szervezeti méret, illetve a vállalati besorolás alapján az 50 fö alatt kisvállalatok azok, amelyek a felhasználóközpontú megközelítések implementálását bizonyos korlátok mellett tudják csak alkalmazni.

\section{ÚJDONSÁGOK}

A különböző UX-es gyakorlatoknak az áttekintése és szintézise a különböző cégek jövendőbeli döntéshozói számára is hasznosak, illetve a szoftverpiacon alkalmazott módszertanok rendszerezett áttekintése tudományos szempontból is újszerü.

Kulcsszavak: felhasználói élmény, emberi tényezök, szoftverfejlesztés, UX érettség 


\section{BEVEZETÉS}

A szoftvertermékek szüken értelmezett előállítási folyamata során a cégek gyakorlatában általában több, nagy hagyománnyal rendelkező, részben szabványosított, egymással rivalizáló modell jelenik meg. Ezek a fejlesztési modellek tipikusan programozáscentrikusak, így azok nehezen illeszkednek a tágabban értelmezett termékmenedzsment folyamatok modelljeibe, valamint alapvetö problémaként azonosítható a felhasználóközpontúság hiánya is.

A technológia fejlődésével átalakuló modern minőségmenedzsment folyamatközpontúvá vált. A folyamatmenedzsment, a folyamatok optimalizálása minden szektorban elengedhetetlen, de különös mértékben érinti a gyorsan változó szoftverpiaci termékeket és fejlesztési folyamatokat (Lee \& Chang 2006). Kulcskérdés a folyamatok folyamatos javítása, mint a TQM vezetési filozófia egyik alapelve (Tenner \& DeToro 1992).

Ennek köszönhetően a szoftverfejlesztési folyamatok állandóan változnak, ami hatással van az implementált felhasználóközpontú szempontok és alkalmazott módszerek alkalmazkodóképességére is.

Az ember-számítógép interakció tudományterületének fejlődése következtében mára a felhasználóközpontú tervezési technikák széles tárháza áll rendelkezésre, hogy az elóállított szoftvertermékek megfelelő felhasználói élményt nyújtsanak (Sikorski 2012). A probléma azonban, ami már jó ideje fennáll, hogy ennek az elismerésnek a fontossága még nem mindenhol jelenik meg a szoftverfejlesztés módszereiben (Seffah et al. 2005, Capretz 2014, Lenberg et al. 2015).

A különféle szoftvertermékek előállítása során az eltérő méretü és profilú cégek más és más szoftverfejlesztési módszertanokat követnek, amelyek befolyásolják a felhasználóközpontú megközelítések integrálhatóságát és annak mértékét, így a kutatás szempontjából alapvető kifejezések is mást jelentenek a szervezetek szereplöi számára.

Ilyen kifejezés például az ISO 9241-210:2010 szabványban is előforduló használhatóság (Hercegfi 2005, Rubin et al. 2008), vagy a manapság gyakran a siker kulcsaként azonosított felhasználói élmény (Sharp et al. 2007) fogalma.

A felhasználói élmény (User eXperience) azon benyomások, érzések összességét takarja, ami a felhasználóban keletkezik egy termék (például szoftver) használata közben. A meghatározásával számos tudományos publikáció foglalkozik, boncolgatva a kifejezés pontos jelentését (Hassenzahl \& Tractinsky 2006, Law et al. 2009).
A vállalati UX-es gyakorlatoknak az áttekintése és szintézise a különböző (nem csak szoftveres) cégek jövendőbeli döntéshozói számára is hasznosak, illetve a szoftverpiacon alkalmazott módszertanok rendszerezett áttekintése tudományos szempontból is újszerü.

\section{A SZOFTVERFEJLESZTÉSI MODELLEK FEJLŐDÉSE}

A szoftvertermékek fejlesztése során alkalmazott aktuális trendek különböző utakat jártak be a közelmúltban, amelyek alapvetően határozzák meg a felhasználóközpontú szempontok és a kapcsolódó módszertanok alkalmazhatóságát. A gyakorlatban igen sokféle, idealizált, hagyományosnak tekinthető szoftverfejlesztési modell érhető el a különféle vállalatok számára, amelyek Mohapatra (2009) értelmezése szerint négy alapkategóriába sorolhatók be: ezek a kódolás és javítás, a vízesés, az evolúciós és spriál típusú modellváltozatok.

A kezdetekben a szoftveres projektek során a követelmények minden esetben ismertek voltak, így a tényleges fejlesztési folyamat csak kódolási és javitási tevékenységekből állt. Az idő múlásával azonban ez a „modell” már egyáltalán nem bizonyult alkalmazhatónak, hiszen az informatika térnyerésével együtt a fejlesztési környezetek is dinamikusan változtak, ami miatt a szoftvertermékek előállítása szisztematikusabb módszert igényelt.

A SAGA légvédelmi szoftverprojekt hatására Benington (1983), Rosove (1967) és Royce (1970) megalkotta a szoftverfejlesztési folyamatok vízesés modelljét. Ebben a modellben a fejlesztési szakaszok lépcsőzetesen kapcsolódtak egymáshoz, ahol a következö lépés csak akkor vehette kezdetét, amikor az előző lezárult (Birell-Ould, 1988). Ez a fejlesztési megoldás volt akkoriban a legtöbb szoftverbeszerzési eljárás alapja, idővel azonban kiderült a módszer legnagyobb hátránya: a szinte minden fázisban megjelenő részletes dokumentáció, mint sikerkritérium elvárás - főleg a követelmények meghatározása és a rendszertervezés tekintetében (Boehm 1988).

Ezért a későbbiekben megjelenő evolúciós modell már lehetővé tette a különböző fejlesztési tevékenységek egyidejű végzését. A gyors visszacsatolás és a megfelelő funkcionalitású rendszer létrehozása érdekében a modell a folyamatosan müködő (vevőnek bemutatható) szoftvertermék elóállítására koncentrált (Denning et al. 2008). Ezeket az alapokat használta fel a későbbiekben az inkrementális, illetve a prototípus-központú fejlesztési megközelítés is. 
A spirál modell a szoftverek fejlesztési folyamatára spirál formában tekintett, így a lépéseket egymást nem követő tevékenységek sorozataként kezelte. A szoftverfejlesztési modellek között ez volt az első olyan, amely nagyobb hangsúlyt helyezett a kockázatelemzésre (Munassar \& Govardhan 2010).

$\mathrm{Az}$ elmúlt évtizedekben ezekre a modellekre építve igen sokféle, hagyományosnak már kevésbé tekinthető szoftverfejlesztési megközelítés alakult ki - például a komponens alapú fejlesztés (Gorton et al. 2006), a win-win spiral változat (Boehm et al. 1998), vagy a RUP folyamatmodell (Kruchten 2000). Ezek mind iteratív és inkrementális megoldások, amelyek középpontjában már a változó megrendelői követelményeknek való megfelelés áll.

Manapság a leginkább elterjedt fejlesztési módszer az agilis, amelynek a legfontosabb elemeit az Agilis kiáltvány tartalmazza, amit az irányzat követei fogalmaztak meg (Fowler \& Highsmith 2001) a 2000-es években. Az agilis együttmüködésre építő, folyamatosan fejlődő, minőségfókuszú fejlesztési megközelítés, amelynek a gyökerei a Lean menedzsment és a Kaizen módszer elemeire vezethetők vissza (Dingsøyr et al, 2012). A korábbi modellekkel ellentétben ez a módszertan és az abban használt eszközök már sokkal inkább koncentrálnak a piaci változásokra és a vevőkkel való folyamatos kommunikációra, előtérbe helyezve a felmerülő igényekkel kapcsolatos visszajelzések rugalmas menedzselését (Mohapatra 2009).

Ez a módszertan tehát igen gyorsan teszi lehetővé a felmerülő változások menedzselését a termékfejlesztés irányába. Ezeknek a rövidtávon bekövetkező változásoknak a megvalósítása rugalmas hozzáállást igényel, amelyet a szervezetek érték-alapú gondolkodással tudnak megvalósítani, a korábbi terv-alapú megközelítés helyett. A gyakorlatban éppen ezért az agilis módszertanokat gyakran kombinálják az emberközpontú tervezés aspektusaival (Schön et al. 2017).

\section{A KUTATÁS ISMERTETÉSE}

\section{A kutatás célja és módszere}

A kutatás célja a különböző típusú szoftvertermékek előállítási folyamatának megismerése, hogy abban a gyakorlatban a felhasználóközpontú szempontok hogyan jelennek meg. A kutatás tehát a szoftverfejlesztés modelljeinek gyakorlati megvalósításaiban kívánja megtalálni a használhatóság és a felhasználói élmény szempontjainak és módszereinek szerves helyét.

A felhasználóközpontú szempontok fontosságának felismerése óta a témához köthetően számos publikáció jelent meg, de ezeknek a munkáknak a nagy része a téma elméleti hátterének az ismertetésével foglalkozik, így például az emberi tényezők számbavételének a fontosságát tárgyalja (Backhaus et al. 2014). A legújabb empirikus kutatások pedig egy-egy konkrét módszertan (például használhatósági vizsgálat), vagy eszköz (például hangos gondolkodás) gyakorlati használatának a lehetőségeit és korlátait ismertetik speciális szoftverekhez kapcsolható alkalmazási területekhez köthetően (May 2018, Brown \& Kim 2018). Nemzetközi szinten ennél átfogóbb, a jelenlegihez hasonló kutatásról csak Andersson (2012) munkája nyomán beszélhetünk, amely a UX területhez köthető tervezési irányelvek vállalati implementálásának a kérdéseit vizsgálja hasonló eszközökkel.

A jelen kutatás az előbbiekkel ellentétben nem egy módszer, vagy egy eszköz, vagy egy irányelv-csoport szoftverfejlesztési gyakorlatban való megjelenítését kutatja, hanem általában az emberközpontú folyamatok meglétét és milyenségét.

A szoftvercégek ilyen jellegü, jelenlegi gyakorlatának a fejlesztési folyamatok mentén történő komplex feltérképezése (alkalmazott modellek, a használhatósággal és felhasználói élménnyel kapcsolatos módszerek integráltság) így tehát tudományos szempontból valóban újszerü. Ez a kérdéskör egy a jelen kutatásra épülő, nagyobb (15-20 fős) interjúsorozat segítségével tárható fel. Mivel a magyar piacon igen jelentős és igen különböző szoftverfejlesztö vállalatok vannak jelen, így egy a hazai mintán elvégzett kutatás alkalmas a kérdés vizsgálatára.

Ez az összehasonlító, feltáró jellegü kvalitatív kutatás UX szakértőkkel, vagy hiányuk esetén fejlesztési vezetőkkel, projektvezetőkkel kerül elvégzésre a cégek valós gyakorlatának és a válaszadók témával kapcsolatos gondolkodásmódjának a megismerése érdekében.

Jelen cikk ennek a nagyobb kutatásnak a kutatási kérdéseit és elözetes eredményeit mutatja be öt igen különböző interjú kvalitatív összegzésének a segítségével. 


\section{Kutatási kérdések}

A szoftvercégek ugyan számtalan elöre definiált szempont (például vállalkozási forma, méret, bevétel; előállított szoftvertermékek típusa, funkciója, kereskedelmi kategóriája) szerint csoportosíthatók, de jelen kutatás szempontjából releváns kérdés az is, hogy milyen típusú vállalatok azonosíthatók az alkalmazott fejlesztési modellek tekintetében. A kisebb létszámú szoftveres cégeknél (tipikusan mikro-, vagy kisvállalatoknál) előfordulhat, hogy a fejlesztés ad hoc módon történik, így ott a különböző modellek használata várhatóan nem (vagy csak részben) jelenik meg. Az ennél nagyobb méretủ vállalkozásoknál pedig a hatékonyság növelése és a projektek nyomon követhetősége érdekében már a fejlesztési modellek, vagy az agilis elemek tudatos alkalmazása is biztosan megvalósul.

Központi kutatási kérdés az is, hogy a különböző szoftverpiaci szervezetek életében a felhasználóközpontú szempontok hogyan jelennek meg a fejlesztési folyamat lépései során, azokkal a szervezet mely szereplöje és milyen formában foglalkozik (1. ábra) (Szabó - Hercegfi 2017).

\section{1. ábra: A felhasználóközpontú szempontok és UX-es szereplók megjelenése a szoftvercégek életében}

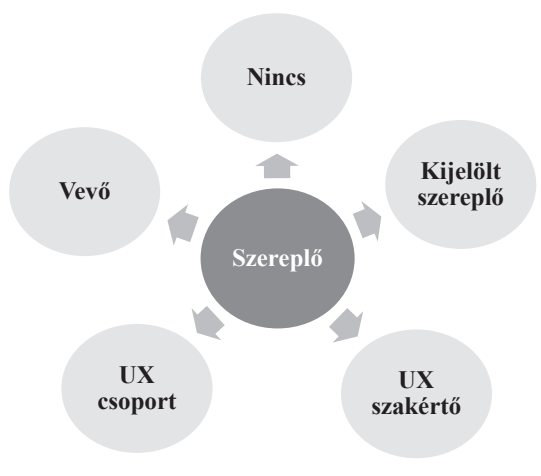

Forrás: saját szerkesztés

Az elmúlt években a felhasználói élmény tervezése és általában az emberi tényezők kulcsfontosságúvá váltak számos üzleti modellben (Salvendy 2012), de még mindig vannak olyan technológiai vállalatok, ahol ezek a faktorok nem töltenek be központi szerepet a szervezet életében. Az emberi tényezők figyelembevételének a hiánya komoly problémát jelent a különböző felhasználóközpontú módszertanok széleskörü elfogadása és alkalmazása tekintetében. Ezért ma már kialakításra kerültek olyan modellek is, amelyek különbözö, a felhasználói élménnyel összefüggésbe hozható aldimenziók mentén határozzák meg a szervezetek UX érettségét (Chapman \& Plewes 2014). Így jelen téma kapcsán a vizsgálat tárgyát képezi az is, hogy a különböző cégek mely szintre sorolhatók a UX érettségi modell értékelése szerint (2. ábra) (Fraser \& Plewes 2015) 

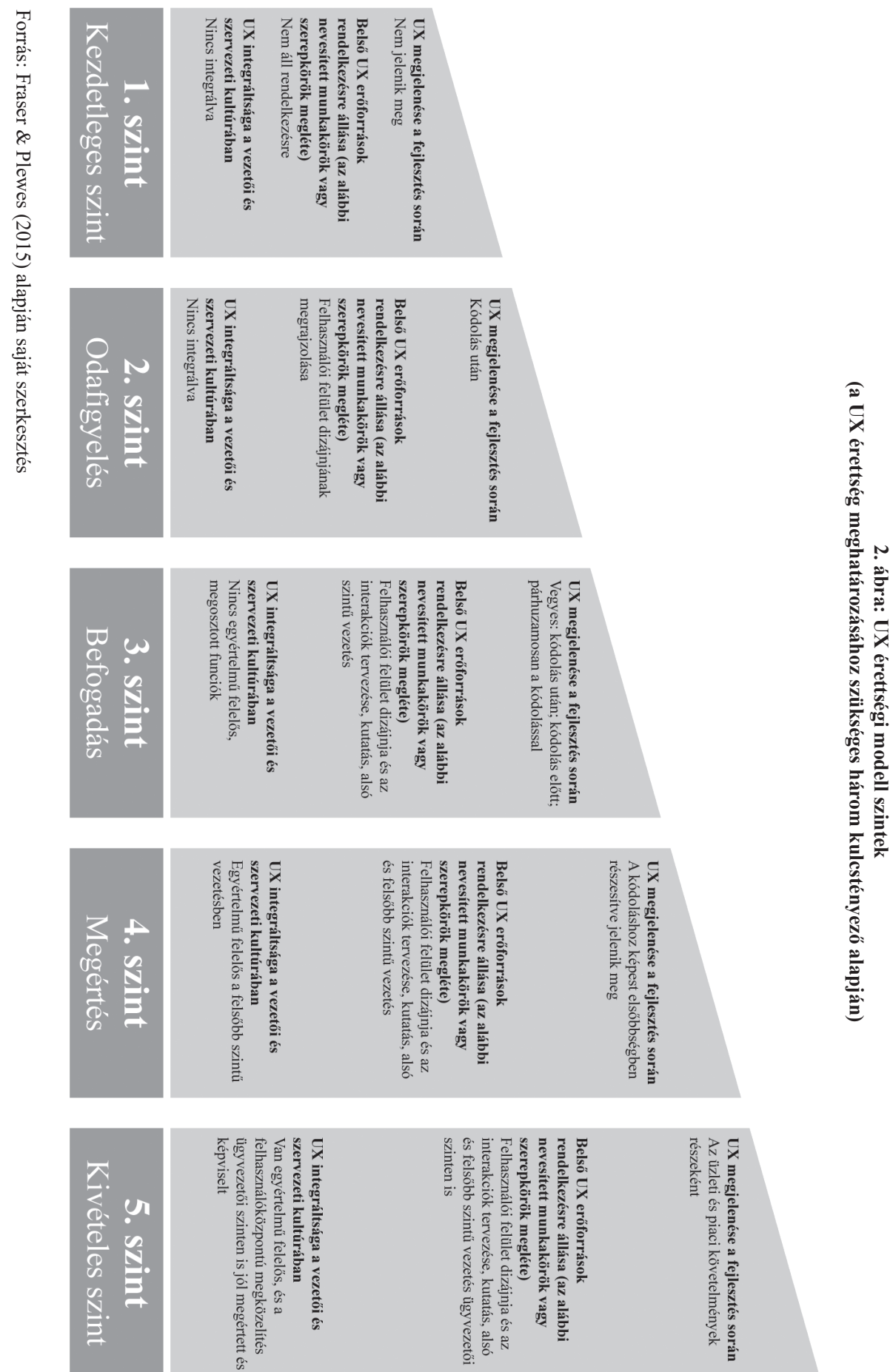


\section{EREDMÉNYEK}

A feltáró kutatás eredményei alátámasztják, hogy a különböző méretủ és profilú vállalatok müködése a szoftverfejlesztés egyes aspektusainak tekintetében valóban igen különböző módon működnek, illetve elmondható az is, hogy a kapott információk ismeretében a vállalatok UX érettségi besorolása elvégezhető a 3. ábrán szereplő három kulcstényező alapján.

Az előzetes elvárásoknak megfelelően a fejlesztés mindenhol eltérő lépések mentén történik, melyek a szakirodalmakban definiált életciklus modellekre (Mohapatra 2009) csak részben hasonlítanak, mivel azok gyakran egyedi tevékenységekkel és agilis elemekkel kerülnek kiegészítésre.

\section{Elsö vállalat}

Az első vállalat egy 300 fös középvállalkozás, ahol a szoftvertermékek elöállítása egy fejlesztő alapcsapat (core team), illetve piaci szakértők bevonásával történik. A fejlesztési igények vagy belsőleg (saját stratégia és vízió lapján) kerülnek megfogalmazásra; vagy pedig külső forrásból (ügyfelektől) származnak.

A szoftverfejlesztési folyamat első lépése a stratégiai tervezés, amelynek a lényege egy olyan verzióterv létrehozása, amely megfelel a vállalat stratégiai szintű elképzelésének. Ezután a második lépés a kickoff fázis, ahol tapasztalt szakemberek döntenek az elképzelés megvalósíthatóságáról. Ezt követi a tervezési szakasz, amelynek a célja a pontos követelmények meghatározása, a költségelemek becslésével egyetemben. A negyedik szakasz pedig a fejlesztés, amelynek akkor van vége, ha az a fejlesztési vezető és felelős designer által is jóváhagyásra került. A következő (release for testing) szakasz során belső és automatizált tesztelések zajlanak. A végső release (kiadás) akkor történik meg, ha a teszteredmények alapján már nem kell változtatásokat eszközölni.

\section{Második vállalat}

A második vállalat egy 1000 fő fölötti nagyvállalat, amelynél az interjúalany egyetlen termék felhasználói felületének kialakításával kapcsolatban tevékenykedik. A fejlesztési igények három forrásból (a $\mathrm{K}+\mathrm{F}$ osztály irányából, a piacról, vagy közvetlenül a megrendelőtől) származnak.

A fejlesztési folyamat megvalósithatósági tanulmányok kidolgozásával kezdődik. Ha ezek alapján engedélyezésre kerül, akkor elöször kis valósághüségủ (low fidelity) változatok - például szabadkézi vázlat (sketch), drótváz modell (wireframe) -, majd nagy valósághüségü (high fidelity) modellek - például makett (mockup) - készülnek, amelyekből prototípus készül (a szoftver még nem végleges, de már tesztelhető változata). A valósághűség dimenziója mentén eltérő változatok lehetővé teszik a felhasználók bevonását a tervezési folyamatba, így biztosítva a felhasználói felületek megfelelő irányú evolúcióját (Wong et al, 2012). A cégnél manuális és automatizált tesztelés is zajlik, amely eredményei alapján a prototípus a módosításra kerül a végső release előtt.

\section{Harmadik vállalat}

A harmadik vállalat egy 200 fős középvállalkozás, ahol a fejlesztési folyamat első fázisa a feltárás (discovery) szakasza. Itt különböző kutatási módszerekkel határozzák meg a pontos felhasználói igényeket. A cél a problématér alapos megismerése, tehát a probléma azonosítása és a megoldás definiálása, ami az ember-számítógép interakció területén a szoftver használatához szükséges kognitív és egyéb tevékenységek összességét érinti (Liu et al. 2014).

A következő fázis a szoftverépítés (build), amely a müszaki fejlesztések összességét takarja. Ha az megfelelőnek bizonyul a döntési kompetenciával rendelkező vezetők számára, akkor következhet a minőség-ellenőrzés, amelynek a célja, hogy a szoftvertermékek teljesek és konzisztensek legyenek (Schulmeyer 2008). Ezek után a folyamat utolsó lépése a visszamérés (measure), ami a kész szoftverváltozat konkrét adatokkal történő visszamérést takarja.

\section{Negyedik vállalat}

A negyedik nagyvállalatnál jelenleg 600 fö dolgozik egy olyan szoftver fejlesztésén, ami felhöalapú szolgáltatás formájában segíti egy adott szakterület napi munkáját. Itt a fejlesztési igények a felhasználóktól érkeznek, vagy a cég $\mathrm{K}+\mathrm{F}$ tevékenysége definiálja őket.

A termékfolyamat az üzleti/felhasználói igény megjelenésével kezdődik, ami a szoftverek B2B jellege miatt negyedéves ciklusokra van felosztva. A folyamat egy feltáró (discovery) résszel indul, ahol felhasználói és technológiai igényfelmérés, valamint érték (value) keresés történik. Majd ezt követi egy design sprint, ahol a csapat tagjai összeülnek, hogy pontosítani tudják az igényeket. A design sprint egy rugalmas terméktervezési 
keretrendszer, amely iterációs lépésekben biztosítja annak a valószínüségét annak, hogy olyan termék keletkezik, ami megfelelő a felhasználók számára (Banfield et al. 2016).

A termékvizió fázisban a design sprint eredmények alapján mockup változatok készülnek, majd definiálásra kerülnek a fejlesztői feladatok a technikai tervezés során. Ezután a fejlesztés, design kialakitás, majd a tesztelés következik. Release közelében pedig a szoftver próbavizsgálata (pilotolás) a folyamat utolsó lépése.

\section{Ötödik vállalat}

Az ötödik cég egy kisvállalat, amely B2B szoftvert fejleszt kereskedelmi cégek informatikai támogatása érdekében. A fejlesztési igények három forrásból származnak, így azok belsőleg fogalmazódnak meg, valamint a szoftverintegrálási folyamat áttekintési fázisában, vagy a tényleges használat közben keletkeznek.

A szoftverfejlesztési folyamat első lépése az igény megismerése, amit egy döntési pont követ, ahol mérlegelik a felmerülő igény megvalósíthatóságát. Pozitív elbírálás esetén következik a specifikáció elkészítése, amit a feladatok kiosztása, majd a tényleges fejlesztés, tesztelés és élesítés fázisa követ.

\section{Agilis módszertanok alkalmazása}

Az agilis fejlesztési módszertanok jelentős hatással vannak a szoftverfejlesztésre és a felhasználói szempontok alkalmazhatóságára, ezért a kutatás külön vizsgálja az agilis módszertanok gyakorlatban való megjelenésének módját és megítélését.

\section{Elsö vállalat}

Az első vállalat a szoftvertermékek fejlesztése során saját módszertannal dolgozik. Mivel az agilis módszertanoknál a „,tervezés kevésbé hangsúlyos” mint a vízesés modellnél, így ,hatékonyabb munkát eredményez”, így a menedzsment „bizonytalanságban él” azzal kapcsolatban, hogy milyen termék is készül pontosan. Ezért a fejlesztések során a vállalatnál két módszertan között egyensúlyoznak a hatékonyság és előreláthatóság közötti optimum megtalálása érdekében. Az interjúalany véleménye szerint az agilis fejlesztésben „komoly lehetőségek" vannak.

\section{Második vállalat}

A második vállalatnál a termék fejlesztése agilis módon valósul meg, a Scrum eszköztár elemeinek alkalmazásával. A Scrum egy keretrendszer, ami bizonyos mértékig szabályozza a hatékonyabb munkavégzés érdekében, hogy mi és hogyan tehető meg, a Scrum Master pedig az a szereplö, aki ennek a betartásáért felel (Larman 2004).

$\mathrm{Az}$ interjúalany véleménye szerint az agilis módszerek alkalmazásának előnye, hogy „lehetôvé teszi a csapaton belüli gyakori visszajelzést”, „,egyértelmúen leosztja a felelősségeket” és ,jól koordinálja a terhelést". Hátránya pedig, hogy „a fejlesztés sok lépésben érintkezik a megrendelővel", ami nehézséget okoz.

\section{Harmadik vállalat}

A harmadik vállalatnál a szoftverfejlesztés szintén a Scrum eszköztár elemeinek alkalmazásával valósul meg. Az interjúalany elmondása szerint „máshogy nem lehet fejleszteni”, csak és kizárólag agilis módon, különben összeomlik a termékfejlesztés. Ezen túl még azért is hasznos, mert „bizonyos szervezeti méret és komplexitás fölött már mindenképpen rendszerben kell gondolkozni”.

\section{Negyedik vállalat}

A negyedik vállalatnál a szoftverfejlesztés agilis módon történik, azon belül is az eXtreme Programming (XP) az, amit a leginkább alkalmaznak. Az XP egy szoftverfejlesztési módszertan, amelynek célja a változó körülmények mellett történő magas minőségü szoftver-előállítás. Az interjúalany véleménye szerint „,a UX csak és kizárólag ebben a formában lehet eredményes", mivel az agilis projektek fordítják a lehető legnagyobb figyelmet fordítják a felhasználói igények megismerésére (Babar et al. 2013).

\section{Ötödik vállalat}

Az ötödik vállalatnál a fejlesztések korábban a vízesés modell lépéseinek megfelelően zajlottak, ma már azonban saját fejlesztési módszertanokat követnek (például az agilis módszertani eszközöket szükebb határidőkkel alkalmazzák, gyorsabban reagálva a felmerülő fejlesztési igényekre). A megkérdezett elmondása szerint ,az agilis fejlesztés általánosságban a nagyobb szervezeteknél, hosszabb projekteknél hasznos". 


\section{Felhasználóközpontú szempontok megjelenése}

A cégeknél nemcsak a fejlesztési folyamatok különböznek egymástól, hanem a felhasználóközpontú szempontok is eltérő módon jelennek meg a különféle lépések mentén.

\section{Elsö vállalat}

Az első vállalatnál a szoftvertermék előállítása során a tervezési, fejlesztési és tesztelési szakaszokban is megjelennek a felhasználók 5-6 fös online fókuszcsoport keretein belül, ahol specifikációs elképzeléseket, köztes verziókat láthatnak. A szervezetnél tevékenykedő, felhasználói élménnyel foglalkozó 10 fös termékmenedzser csoport így biztosítja a folyamatos iterációt a felhasználókkal a fejlesztés során.

\section{Második vállalat}

A második vállalatnál a felhasználói felületek tervezése során a 3 fős UX-es csapat különbözö víziókat definiál, amelyekhez felhasználókat, majd perszonákat rendelnek. A perszonák tipizált felhasználók, amelyek kialakítása növeli a termékfejlesztési folyamat hatékonyságát (Miaskiewicz \& Kenneth 2011). Ezek után feladatuk a user journey map összeállítás, ami annak a folyamatnak a vizualizációja, amelyen egy felhasználó végighalad egy adott cél elérése érdekében (Rosenbaum et al. 2017). A cégnél a felhasználói felületek tesztelése belsőleg zajlik, heurisztikus módon.

\section{Harmadik vállalat}

A harmadik vállalatnál a 7 fös UX-es egység munkatársai egyszerre több csapattal, szorosan együttmúködve dolgoznak. Az interjúalany szerint a cég sikere a felhasználóközpontú szervezeti kultúrának köszönhető, ami a fejlesztési folyamatra is kihat, hiszen abban minden ponton megjelennek a felhasználók valamilyen módon. A felhasználók bevonása exploratív interjúkkal, megfigyelésekkel, a naplóírás technikájának alkalmazásával történik, valamint különféle használhatósági tesztelésre is sor kerül (sokszor RITE formában). A Rapid Iterative Test and Evaluation egy olyan módszer, ami - egy felhasználó bevonásával, az eredmények azonnali kiértékelésével, módosítások átvezetésével a gyors megoldások megtalálására fókuszál a problémák feltárása helyett (Medlock et al 2005).

\section{Negyedik vállalat}

A negyedik vállalatnál a különféle célokat OKR (Objectives and Key Results) rendszerben rögzítik. Az OKR egy keretrendszer, ami arra törekszik, hogy a közös gondolkozás és cél (itt olyan eredménytermék eloállítás, ami megfelel a felhasználói igényeknek) megléte révén biztosítsa az alkalmazottak együttmüködését, hogy erőfeszítéseikkel arra törekedjenek, hogy mérhető hozzájárulásokat tegyenek a vállalat sikereihez (Niven \& Lamorte 2016).

A fejlesztési folyamat során a 7 fös UX csapat munkatársai szabad eszköztárral dolgoznak, amelyek közül a naplózás, interjú, kontextusba helyezett megkérdezés, használhatósági vizsgálat az a módszer, ami a leggyakrabban megjelenik.

\section{Ötödik vállalat}

Az ötödik vállalatnál UX típusú feladatokkal nem foglalkozik senki. A cégnél a felhasználói felület tervezése egyfajta hagyománykövetési elv alapján müködik, ami azt jelenti, hogy van egy alap design és az egységesség érdekében az ott felhasznált stílust és kinézetet alkalmazzák, amely kialakítása során figyelembe vesznek különbözö felhasználóközpontú tervezési elveket is (például egér nélküli használat, átlátható képernyőképek). A tesztelés során a munkatársak mindig valós felhasználói teszteket szimulálnak.

\section{EREDMÉNYEK ÖSSZEGZÉSE}

Az előzetes eredmények jól szemléltetik, hogy a szoftverfejlesztési folyamatokban jelentős eltérések vannak, így a felhasználók bevonása is eltérő pontokon, más-más módszerek alkalmazásával tud megvalósulni (3. ábra) 


\section{3. ábra: A felhasználóközpontú szempontok megjelenése a vállalatok szoftverfejlesztési folyamataiban}

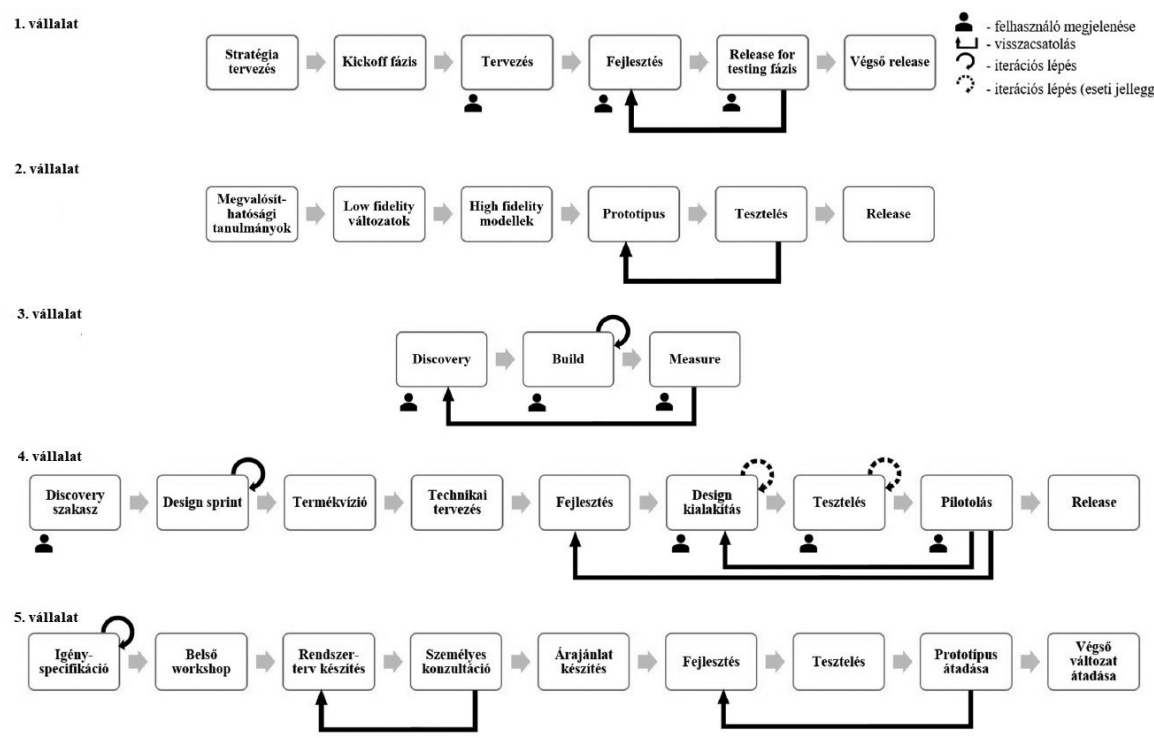

Forrás: Saját szerkesztés

A fejlesztések a legtöbb esetben agilis módon zajlanak (vagy egyedi módszertan mentén, agilis elemek átemelésével), de ennek ellenére azokban a vártnál kevesebb a visszacsatolás. Elmondható az is, hogy ugyan a vállalatok jelentős részénél már agilis módon fejlesztenek, de úgy tünik, hogy nem ez a tényező határozza meg a szervezetek UX-es érettségét. A második vállalat „tisztán” agilis müködés mellett 2-es, míg hasonló keretek között a negyedik szervezet már 5-ös szintre sorolható a Fraser-Plewes féle UX érettségi modell alapján.

A UX érettség magasabb (4-es és 5-ös szintre tehetö) azoknál a vállalatoknál, ahol a felhasználóközpontú megközelítéssel foglalkozó csapatok tevékenységeke a szervezet egészére kiterjedt. Itt a modell tényezőinek megfelelően a „Kivételes” szint elérése valóban azon cégekre lehet jellemzö, ahol a UX-es tevékenységek a fejlesztési folyamat minden lépése mentén jelen vannak. A feltáró kutatás eredményei alapján ehhez tipikusan 7 fös UX-es csapatra van szükség. Ennél kisebb létszám esetén (második vállalat) a felhasználóközpontúság nem tud megfelelően megjelenni a teljes szervezetben, míg nagyobb elemszámú csapat esetén a UX érettség alacsonyabb lehet (első vállalat). 


\section{1. táblázat - A kvalitatív kutatás eredményeit összefoglaló táblázat az első öt szoftvercég vonatkozásában}

\begin{tabular}{|c|c|c|c|c|c|}
\hline Azonosító & 1 & 2 & 3 & 4 & 5 \\
\hline Életkor & 25 év fölött & 25 év fölött & 10-15 év & 5-10 év & 20-25 év \\
\hline Létszám & 300 fö & 1000 fö fölött & 200 fő & 600 fö & 40 fö \\
\hline Vállalati kategória & Nagyvállalat & Nagyvállalat & Középvállalat & Nagyvállalat & Kisvállalat \\
\hline $\begin{array}{l}\text { Tulajdonosi } \\
\text { megoszlás }\end{array}$ & $\begin{array}{c}\text { Multi- } \\
\text { nacionális }\end{array}$ & $\begin{array}{c}\text { Multi- } \\
\text { nacionális }\end{array}$ & $\begin{array}{c}\text { Transz- } \\
\text { nacionális }\end{array}$ & $\begin{array}{c}\text { Multi- } \\
\text { nacionális }\end{array}$ & $\begin{array}{c}\text { Transz- } \\
\text { nacionális }\end{array}$ \\
\hline Profil & $\mathrm{B} 2 \mathrm{~B}$ & $\mathrm{~B} 2 \mathrm{~B}$ & $\mathrm{~B} 2 \mathrm{C}$ & $\mathrm{B} 2 \mathrm{~B}$ & $\mathrm{~B} 2 \mathrm{~B}$ \\
\hline Szoftver típusa & $\begin{array}{l}\text { Dobozos } \\
\text { szoftver } \\
\text { egy széles } \\
\text { szakmai kör } \\
\text { számára }\end{array}$ & $\begin{array}{l}\text { Felhőalapú } \\
\text { szoftver egy } \\
\text { szük szakmai } \\
\text { kör számára }\end{array}$ & $\begin{array}{l}\text { Felhőalapú } \\
\text { szoftver } \\
\text { elsősorban } \\
\text { magánszemé- } \\
\text { lyek számára }\end{array}$ & $\begin{array}{l}\text { Felhőalapú } \\
\text { szoftver egy } \\
\text { szük szakmai } \\
\text { kör számára }\end{array}$ & $\begin{array}{c}\text { Felhőalapú } \\
\text { szoftver, } \\
\text { egyedi } \\
\text { tanácsadás- } \\
\text { sal / testre } \\
\text { szabással egy } \\
\text { szűk szakmai } \\
\text { kör számára }\end{array}$ \\
\hline $\begin{array}{l}\text { Agilis szoftverfej- } \\
\text { lesztési módszertan } \\
\text { alkalmazása }\end{array}$ & $\begin{array}{c}\text { Részben } \\
\text { agilis }\end{array}$ & Agilis & Agilis & Agilis & Iteratív \\
\hline $\begin{array}{c}\text { UX megjelenése a } \\
\text { fejlesztési } \\
\text { folyamatban }\end{array}$ & Formális & Formális & Formális & Formális & Ösztönös \\
\hline UX csapat létszáma & 10 fö & 3 fö & 7 fö & 7 fö & - \\
\hline $\begin{array}{l}\text { UX tevékenység } \\
\text { kiterjedtsége }\end{array}$ & $\begin{array}{c}\text { Egész } \\
\text { szervezetre }\end{array}$ & $\begin{array}{l}\text { A szervezet } \\
\text { egy részére }\end{array}$ & $\begin{array}{c}\text { Egész } \\
\text { szervezetre }\end{array}$ & $\begin{array}{c}\text { Egész } \\
\text { szervezetre }\end{array}$ & - \\
\hline $\begin{array}{c}\text { Felhasználók } \\
\text { bevonása }\end{array}$ & $\begin{array}{l}\text { Tervezés, } \\
\text { fejlesztés, } \\
\text { tesztelés }\end{array}$ & - & $\begin{array}{l}\text { Minden } \\
\text { ponton }\end{array}$ & $\begin{array}{l}\text { Minden } \\
\text { ponton }\end{array}$ & - \\
\hline $\begin{array}{l}\text { Alkalmazott } \\
\text { felhasználóközpontú } \\
\text { módszerek }\end{array}$ & $\begin{array}{l}\text { Online } \\
\text { fókuszcso- } \\
\text { port, hasz- } \\
\text { nálhatósági } \\
\text { tesztelés }\end{array}$ & $\begin{array}{l}\text { Saját analiti- } \\
\text { kus módszer, } \\
\text { irányelvekkel } \\
\text { való ütközte- } \\
\text { tés (guideline } \\
\text { review) }\end{array}$ & $\begin{array}{l}\text { Interjú, hasz- } \\
\text { nálhatósági } \\
\text { vizsgálat }\end{array}$ & $\begin{array}{l}\text { Megfigye- } \\
\text { lés, interjú, } \\
\text { kontextusba } \\
\text { helyezett } \\
\text { megkérdezés, } \\
\text { használható- } \\
\text { sági vizsgálat }\end{array}$ & $\begin{array}{l}\text { Vásárlóköz- } \\
\text { pontú fókusz- } \\
\text { csoport }\end{array}$ \\
\hline UX érettség & 4 & 2 & 5 & 5 & 1 \\
\hline
\end{tabular}

Forrás: Saját szerkesztés 
Az első táblázat alapján további eltérések azonosíthatók a fejlesztés során megkérdezett felhasználók számában, illetve a bevonásuk során alkalmazott módszerek tekintetében is. Jelen kutatás alapján a legtöbb felhasználó bevonásával müködő (harmadik) vállalatról elmondható, hogy B2C terméket gyárt, szélesebb felhasználói kör számára, így az előállított szoftvertermék típusa több dimenzió mentén befolyásolhatja a szervezetek UX-es érettségét.

A kapott eredmények alapján kijelenthetö, hogy az empirikus módszereket alkalmazó középés nagyvállalatok (első, harmadik és negyedik szervezet) a méretüktöl függetlenül tudatosabban és sikeresebben implementálták a UX-es folyamatokat, amely során a saját müködésüknek megfelelő felhasználóközpontú módszereket alkalmazzák. Az eszköztár igen vegyes, így azok között jelen van felhasználói megfigyelés, interjú, online fókuszcsoport és a kontextusba helyezett megkérdezés is, míg közös jellemző a különböző pontokon megjelenő használhatósági vizsgálatok alkalmazása.

Az eredmények alapján elmondható az is, hogy a szervezeti méret, illetve a vállalati besorolás alapján az 50 fö alatt kisvállalatok azok amelyek a felhasználóközpontú megközelítések implementálását bizonyos korlátok mellett tudják csak alkalmazni. Az ilyen cégek közös jellemzője, hogy a felhasználók bevonása helyett inkább a vásárlók megkérdezésére törekednek a müködésük során, tehát a felhasználóközpontúság csak ösztönös módon van jelen a fejlesztési folyamatokban.

\section{ÖSSZEFOGLALÁS ÉS KITEKINTÉS TOVÁBBI KUTATÁSOKRA}

Jelen feltáró jellegű, kvalitatív kutatás alátámasztja a szoftveres cégek sokszínű működését és azt, hogy azonosíthatók olyan tényezök, amelyek befolyásolhatják a felhasználóközpontú szempontok alkalmazhatóságát és a szervezeti UX érettség szintjét. Ezek a feltételezett összefüggések az interjúk elemszámának növelésével hipotézisek formájában fogalmazhatók meg, amelyek kérdöíves megkérdezés segítségével statisztikailag is igazolhatók, vagy cáfolhatók. Ez a kutatás a 15-20 fös mintán elvégzett interjús megkérdezés után UX-es szakmai közösségekben terjesztve kerül majd kiküldésre a kérdéskör kvantitatív vizsgálata érdekében. 


\section{HIVATKOZÁSOK}

Andersson, S. (2012), Development and Implementation of User Experience Interaction Guidelines, Uppsala: Uppsala Universitet

Babar, M. A., Brown, A. W., Mistrik, I. (2013), Agile Software Architecture: Aligning Agile Processes and Software Architectures, San Francisco: Morgan Kaufmann Publishers DOI: https://doi.org/10.1016/C2012-0-01208-2

Backhaus, N., Brandenburg, S., Trapp, A. (2014), „Positive Technology and User Experience for Human Needs in Developing Countries: Some Considerations", in: Marcus, A. (ed.), Design, User Experience, and Usability. User Experience Design Practice: 3rd International Conference, Heraklion: Springer, 400-10 DOI: https:// doi.org/10.1007/978-3-319-07635-5_39

Banfield, R., Lombardo, C. T., Trace, T. (2016): Design Sprint - A Practical Guidebook for Building Great Digital Products, California: O'Reilly Media

Birrell, N. D. and Ould, M.A. (1988): A practical handbook to software development; Cambridge University Press. ISBN 978-0521347921. 3-12

Boehm, B. W. (1988), "A spiral model of software development and enhancement", Computer, 21 5, 61-72 DOI: https://doi.org/10.1109/2.59

Boehm, B., Egyed, A., Kwan, J., Port, D., Shah, A., Madachy, R. (1998), "Using the WinWin Spiral Model: A Case Study", Computer, 31 7, 33-44 DOI: https://doi.org/10.1109/2.689675

Brown, J., Kim, H. N. (2018), "Usability of Alzheimer's mHealth Applications", Journal of Best Practices in Health Professions Diversity: Education, Research \& Policy, 62 1, 503-7

Capretz, L. F. (2014), „Bringing the human factor to software engineering", IEEE Software, 312 , 102-4 DOI: https://doi.org/10.1109/ms.2014.30

Chapman, L., Plewes, S.: (2014), „A UX Maturity Model: Effective Introduction of UX into Organizations", in: Marcus A. (eds.), Design, User Experience, and Usability. User Experience Design Practice, 3rd International Conference, Heraklion: Springer, 12-23 DOI: https:// doi.org/10.1007/978-3-319-07638-6_2

Denning P. J., Gunderson C., Hayes-Roth R. (2008), „Evolutionary system development”, Communications of the ACM, 51 12, 29-31

Dingsøyr, T. - Nerur, S. - Balijepally, V. - Moe, N. B. (2012): „A decade of agile methodologies: Towards explaining agile software development." The Journal of Systems and Software 85 6, 1213-1221 DOI: https://doi.org/10.1016/j. jss.2012.02.033
Fraser J., Plewes S. (2015), „Applications of a UX Maturity Model to Influencing HF Best Practices in Technology Centric Companies: Lessons from Edison", Procedia Manufacturing, 3 626-31 DOI: https://doi.org/10.1016/j. promfg.2015.07.285

Fowler, M., Highsmith, J. (2001), "The agile manifesto", Software Development, 9 8, 28-35

Gorton, I., Heinemann, G. T., Crnkovic, I., Schmidt, H. W., Stafford, J. A., Szyperski, C., Wallnau, K. (eds.) (2006), Component-Based Software Engineering: 9th International Symposium, Västeras: Springer

Hassenzahl, M., Tractinsky, N. (2006), „User experience - a research agenda", Behaviour \& Information Technology, 25 2, 91-7 DOI: https://doi. org/10.1080/01449290500330331

Hercegfi K. (2005), Multimédia oktatóanyag fejlesztésének és bevezetésének minöségbiztositási kérdései. Budapest: BME Gazdálkodásés Szervezéstudományok Doktori Iskola

ISO 9241-210 (2010), Ergonomics of human-system interaction, Part 210: Human-centred design process for interactive systems, Berlin: Deutsches Institut für Normung

Kruchten, P. (2000), The Rational Unified Process An Introduction, Boston: Addison-Wesley

Law, E. L. C., Roto, V., Hassenzahl, M., Vermeeren, A. P., Kort, J. (2009), „Understanding, scoping and defining user experience: a survey approach", Proceedings of the SIGCHI conference on human factors in computing systems, Boston: ACM, 719-28 DOI: https://doi. org/10.1145/1518701.1518813

Lee, M C., Chang, T. (2006), „Applying TQM, CMM and ISO 9001 in knowledge management for software development process improvement" International Journal of Services and Standards, 2 1, 101-15 DOI: https://doi. org/10.1504/ijss.2006.008161

Lenberg, P., Feldt, R., Wallgren, L. G. (2014), „Towards a behavioral software engineering", Proceedings of the 7th international workshop on cooperative and human aspects of software engineering, Hyderabad: ACM, 48-55 DOI: https://doi.org/10.1145/2593702.2593711

Larman, C. (2004), Agile and iterative development: a manager's guide. Boston: Addison-Wesley Professional

Liu, C., Cheng, R., Meng, S. (2014), ,An Observation of Problem Spaces Based on Human-Computer Interactions", The Open Cybernetics \& Systemics Journal, 8, 139-45 DOI: https://doi. org/10.2174/1874110x01408010139 
May, J. (2018), „YouTube Gamers and ThinkAloud Protocols: Introducing Usability Testing", IEEE Transactions on Professional Communication, 1-10 DOI: https://doi.org/10.1109/ tpc.2018.2867130

Medlock, M. C., Wixon, D., McGee, M., Welsh, D. (2005), ,The Rapid Iterative Test and Evaluation Method: Better Products in Less Time", in: Cost-Justifying Usability, San Francisco: Morgan Kaufmann, 489-517 DOI: https:/doi. org/10.1016/b978-012095811-5/50017-1

Miaskiewicz, T., Kenneth, A. K. (2011), „Personas and user-centered design: How can personas benefit product design processes?", Design Studies, 32 5, 417-30 DOI: https://doi. org/10.1016/j.destud.2011.03.003

Mohapatra, P. K. J. (2009), Software Engineering: a Lifecycle Approach, New Delhi: New Age International Publishers

Munassar, N. M. A., Govardhan, A. (2010), “A comparison between five models of software engineering", International Journal of Computer Science Issues, 7 5, 94-101

Niven, P. R., Lamorte, B. (2016), Objectives and Key Results: Driving Focus, Alignment, and Engagement with OKRs, New Jersey: Wiley DOI: https://doi.org/10.1002/9781119255543

Rosenbaum, M. S., Otalora, M. L., Ramírez, G. C. (2017), "How to create a realistic customer journey map”, Business Horizons, 60 1, 143-50 DOI: https://doi.org/10.1016/j.bushor.2016.09.010

Rosove, P. E. (1967), Developing Computer-Based Information Systems, New York: Wiley

Royce, W. W. (1970): "Managing the Development of Large Software Systems", Technical Papers of Western Electronic Show and Convention, Los Angeles: ACM

Rubin, J., Chisnell, D., Spool, J. (2008), Handbook of Usability Testing: How to Plan, Design, and Conduct Effective Tests, New Jersey: Wiley
Salvendy, G. (2012), Handbook of Human Factors and Ergonomics, New Jersey: Wiley

Seffah, A, Gulliksen, J., Desmarais, M. C. (2005): Human-Centered Software Engineering: Integrating Usability in the Software Development Lifecycle, Dordrecht: Springer DOI: https://doi. org/10.1007/1-4020-4113-6

Schön, E. M., Thomaschewski, J., Escalona, M. J. (2017): „Agile Requirements Engineering: A systematic literature review", Computer Standards \& Interfaces, 49 1, 79-91 DOI: https://doi. org/10.1016/j.csi.2016.08.011

Schulmeyer, G. G. (2008): Handbook of Software Quality Assurance, London: Artech House Inc

Sharp, H., Rogers, Y., Preece, J. (2007), Interaction design: Beyond human-computer interaction. New Jersey: Wiley

Sikorski, M. (2012), User-System Interaction Design in IT projects, Gdansk: Gdansk University of Technology

Szabó, B. - Hercegfi, K. (2017), „Research questions on integrating user experience approaches into software development processes", in: Baranyi, P. (ed.), 8th IEEE International Conference on Cognitive Infocommunications, Debrecen: IEEE, 243-6 DOI: https:/doi. org/10.1109/coginfocom.2017.8268250

Tenner, A. R., DeToro, I. J. (1992), Total quality management: Three steps to continuous improvement, Addison-Wesley

Wong, M. L., Khong, C. W., Thwaites, H. (2012): „Applied UX and UCD Design Process in Interface Design", Procedia - Social and Behavioral Sciences, 51 703-8 DOI: https://doi. org/10.1016/j.sbspro.2012.08.228 
Szabó Bálint, tudományos segédmunkatárs szabobalint@erg.bme.hu

Budapesti Müszaki és Gazdaságtudományi Egyetem

Gazdaság- és Társadalomtudományi Kar

Ergonómia és Pszichológia Tanszék

\section{Different appearance of user-centred aspects in software development - Qualitative research on the practice of domestic companies}

\section{THE AIMS OF THE PAPER}

The aim of the research is to deepen the knowledge on the production process of various software product types, including the detailed examination of how user-centered aspects are applied in software development practice. Therefore, the research aims to explore the role of the usability and User eXperience (UX) factors in the practical implementations of software development models.

\section{METHODOLOGY}

The current practice of software companies can be explored through interview series. A research performed on a sample of 15-20 professional leaders is a good starting point to learn the practice of companies and the attitude of the respondents toward the topic. This paper presents the research questions and preliminary results of this larger research through the qualitative summaries of six very different interviews.

\section{MOST IMPORTANT RESULTS}

Preliminary results show that there are significant differences in software development processes. They are implemented various ways, with the use of several tools, so that users can be involved at different points, using different methods. Developments in most cases are agile, althought, feedback was less than expected. Although in most companies the developments are already agile, but this factor does not seem to determine the UX maturity level of organizations. UX maturity is higher in companies where the user-centered approach activities have been extended throughout the organization. Besides, based on the results, it seems that medium and large enterprises using empirical methods have implemented the UX processes more consciously and successfully, regardless of their size. Based on the results, it can be stated that, according to organizational size and corporate classification, small businesses below 50 employees are those that can only apply the implementation of user-centred approaches under certain limits.

\section{RECOMMENDATIONS}

Overview and synthesis of the various UX practices are useful for future decision-makers of different companies, and a systematic overview of the methodologies used in the software market is also novel from a scientific point of view.

Keywords: User eXperience (UX), human factors, software development, UX maturity 